\title{
Urszula Markowska-Przybyła
}

Wrocław University of Economics

e-mail: urszula.markowska-przybyla@ue.wroc.pl

ORCID: 0000-0002-1340-830X

\section{THE ADDED VALUE OF SOCIAL CAPITAL IN POLAND IN LIGHT OF THE EXPERIMENTAL DATA RENTA KAPITAŁU SPOLECZNEGO W POLSCE W ŚWIETLE DANYCH EKSPERYMENTALNYCH}

DOI: $10.15611 /$ pn.2019.8.05

JEL Classification: C72, D63, E22

Summary: The article presents the issues of social capital, the benefits it can bring and the concept of added value that it can create for companies located in a favorable environment. The purpose of the article is to indicate which regions of Poland and categories of places, due to their size, are more abundant than others in social capital resources and may bring enterprises an extraordinary added value - a social capital added value. The research was based on the results of unique research on social capital - based on the observation of behavior. The research method was the method of experimental economics, the study was conducted on a sample of 1540 people in all regions of Poland in 2014. The second part of the work presents the issues of social capital, its significance and the added value it yields. The third part presents the research method. The fourth one - the essential part of the work - presents the results of the research on the level of the social capital of regions and various classes of towns. The fifth part points to the empirical evidence of the relationship between Poland's social capital (measured on the basis of conducted research) and the economic achievements. The last part is a summary.

Keywords: social capital, added value, regions, Poland, experimental economy.

Streszczenie: W artykule zaprezentowano problematykę kapitału społecznego, korzyści, które może on przynosić, i pojęcie renty, którą może stwarzać dla firm lokalizujących się w sprzyjającym otoczeniu. Celem artykułu jest wskazanie, które regiony Polski i kategorie miejscowości ze względu na wielkość są bogatsze od innych w zasoby kapitału społecznego i mogą przynosić przedsiębiorstwom rentę nadzwyczajną - rentę kapitału społecznego. Badania oparto na wynikach unikatowych analiz nad kapitałem społecznym - bazujących na obserwacji zachowań. Metodą badawczą była metoda ekonomii eksperymentalnej; przebadano próbę 1540 osób we wszystkich regionach Polski (w 2014 roku). W drugiej części pracy przedstawiono zagadnienia kapitału społecznego, jego znaczenia i renty z niego płynącej. W trzeciej zaprezentowano metodę badawczą. W czwartej - zasadniczej części pracy opisano wyniki badań nad poziomem kapitału społecznego regionów i różnych klas miejscowości. W 
piątej części wskazano na empiryczne dowody związków kapitału społecznego Polski (mierzonego na podstawie przeprowadzonych badania) z osiągnięciami gospodarczymi. Ostatnia część stanowi podsumowanie.

Słowa kluczowe: kapitał społeczny, renta, regiony, Polska, ekonomia eksperymentalna.

\section{Introduction}

A broad and comprehensive approach to enterprise management requires the consideration of not only the traditional factors on which competitive advantage can be based, but also unique, increasingly important ones. Competitive advantages are built today not only on the basis of competition, but also on the basis of proper cooperation. It is not just about using resources more efficiently than competitors, but about the right strategy, which is often the proper cooperation within a network of relationships. The decision to locate the company is a strategic decision, and nowadays in an era of growing significance of intangible factors, it may turn out to be crucial. Obtaining human resources with high competences, but also with high morality, credibility, willingness to trust, cooperate and unwilling to break social or legal norms is becoming a key issue. In the time of introducing innovative organizational solutions (empowerment, turquoise companies, sharing economics, virtual organizations), the factors conditioning success are trust and credibility - as its pillars, which are also important factors of social capital.

In decisions on organization location, soft factors, most likely the social capital of the state, region or local community, will probably be of growing importance. A high level of social capital - including trust, credibility and willingness to cooperate - may bring additional, extraordinary benefits to the organization, hence one can speak of the added value of social capital.

The remaining part of the study discusses the theoretical aspects of social capital, its effects and added value related thereto and presents the results of the author's research diagnosing the level of this capital in Poland, including regional diversity and within different types of territories.

\section{Social capital and the added value of social capital}

Social capital has still not been uniformly defined or even interpreted, however, as noted by J. Bartkowski, "the lack of a single and recognized definition is not a consequence of methodological deficiencies and underdevelopment of the field itself, but the complexity and multi-faceted nature of the phenomenon, and an attempt to unilaterally resolve these issues would significantly impoverish his understanding" [Bartkowski 2007, p. 69]. Social capital is considered from different perspectives (neo-Rurkheim, economic, historical and institutional), analyzed at 
various levels (from individual, through group, and finally at macro level), in different approaches (structural, analyzing the normative relationship network, i.e. as the analysis of norms and values and behavioral, and the analysis of specific manifestations of behavior). Social capital is defined with the use of a positive approach (avoiding valuation) and a normative one (subjective, applying valuation), it is treated as an individual good, a common good or public good.

J. Coleman defines social capital as "the characteristics of social life-networks, norms and trust - that facilitate cooperation and coordination of people's actions for the common good" [Coleman 1988]. R. Putnam claimed that social capital "refers to (...) such objectives of a society as trust, norms and relations, which might increase the efficiency of society, facilitating coordinated activities" [Putnam 1995, p. 258]. Similarly, F. Fukuyama defines social capital through the prism of the effectiveness of collective actions and defines it as "the ability to cooperate through informal rules and norms between people within a group and organization in order to realize the interests of members" [Fukuyama 1997].

Taking into account the essence of social capital and contemporary determinants of regional development (such as the way in which production processes are organized, the growing importance of soft factors, including social and cultural factors and their importance for innovation, the growing importance of specific resources of the territory) it seems justified to claim that obtaining a competitive advantage by enterprises is currently associated with obtaining a special economic added value which is the social capital added value. ${ }^{1}$

Traditional production factors providing economic added value were: work giving wages, interest-bearing capital and land providing rent. In addition, the neoclassical economic literature also distinguishes monopoly rent (denoting the benefits of market protection or monopolistic collusion, where the resource is monopoly), entrepreneurial rent (Schumpeterian rent, which is the result of risk-taking and entrepreneurship, here the resource is entrepreneurship, understood as organization or supervision), a quasi-rent. At present the concept of economic rent is applied to all rare, unique factors of production. J. Barney lists the common features of resources that bring a rent. They are rare, they are valuable, they are difficult to copy, they are irreplaceable (i.e. they do not have substitutes) [Barney 1991, in: Kopczewska 2008, p. 45]. Social capital undoubtedly meets all these features and, like geographic rent, is a bonus in the socio-economic development of the area, a bonus for geographical location in a specific geopolitical system [Kopczewska 2008, p. 46], the social capital added value is an additional remuneration, a bonus for functioning in a specific social, cultural and institutional environment.

Another approach may be H. George's concept (later extended by other authors). According to it, social capital can be treated as a factor determined by the location factor, which generates an economic rent in the form of a land rent. H. George

\footnotetext{
1 The concept proposal was presented in: [Markowska-Przybyła 2010].
} 
defined the land factor much broader than D. Ricardo and K. Marx, i.e. as a resource that is neither capital nor labour. It is a residual interpretation, which in practice covers a much wider range of natural resources than traditionally perceived land. In this approach, the ground was somehow detached from the land. The ground factor is treated here as a residual resource comprising a number of values with an inflexible supply. The original definition included, in particular, raw materials, the forces of nature and the possibilities provided by nature, and nowadays this list can include: radio waves, communication infrastructure, internet access, political balance, national culture, and national heritage if they are connected with the ground etc. (cf. [Czyżewski 2009]). This set can also include social capital, which is very poorly mobile.

Operating in a favorable social environment brings a number of direct and indirect benefits to companies. Synthetically, J. Czapiński writes about it: "[social capital] facilitates negotiations, reduces transaction costs, shortens the investment process (reduces the likelihood of challenging subsequent administrative decisions), reduces corruption, increases the reliability of contractors, promotes long-term investment and knowledge diffusion, prevents abuse of the common good and increases inter-group solidarity, and also, through the development of the third sector, promotes social control over the activities of the authorities" [Rada Monitoringu Społecznego 2009, p. 270]. Thanks to trust, a favorable climate is created for the development of partner relations, the decentralization of decisions and control, and free circulation of information. Confidence reduces transaction and control costs, promotes independence (subordinates' activity), unconventional decisions and flexible responses of subordinates [Woźniak 2008, p. 131]. Social capital reduces transaction costs, but it can also increase the number of transactions. K. Arrow believes that generally all transactions require trust, and the lack of trust reduces the number of transactions favorable for each party [Arrow 1972].

Classically understood human capital primarily distinguishes the wealth of individuals, not the wealth of societies, especially in highly developed countries, where the sum of individual advantages does not guarantee team winning in international competition. It is undeniable that human capital is of macroeconomic importance, but the effect of winning in international competition arises only when these better-educated employees interact with each other, which is more than just an individual competence [Czapiński 2008, p. 7]. Today the nature of a given community is as important as the character of individuals. Researchers are increasingly referring to the concept of social capital in order to explain why certain societies tend to be more efficient than their material resources would suggest, indicating that certain factors in the field of culture, psychology or social relations affect the whole that are the bigger entities than the sum of their parts [Pogonowska 2004, p. 11]. Social capital helps to explain how other factors of economic growth (human, physical, financial, etc.) are organized, how they interact, because it is the way of organization that co-decides about success. Social capital can combine 
and more or less effectively use other types of capital [Knowles 2006]. At the same time, social capital has the property of being permanently associated with the territory. It is practically immobile. The processes of its creation are long-lasting, yet its existence is perishable.

By operating in a social environment where the level of generalized trust is higher, the chance to acquire reliable, cooperative employees, trusting clients, reliable suppliers or cooperating organizations, i.e. lowering transaction costs, is also higher. This also affects the creation of network of relationship, the ability to create clusters (and other network systems, e.g. clusters, TSPs, industrial districts) and reap additional benefits.

Higher trust in the organization means an immaterial value for the company, less need for control, formalization of activities, greater independence of employees, better working atmosphere, all of which can have a positive impact on operating costs, lower employee turnover, trust in management, and this factor is particularly important in times of change and crises. Distrustful people are less creative, less committed, closed, do not share their knowledge, and can exhibit opportunistic attitudes. All this translates into the company's image and reputation, and thus to its profitability.

Assuming that acting in an environment of people who are more inclined to cooperate with anonymous people, have higher generalized trust and higher credibility for anonymous and one-off transactions, one may think that such an environment is more conducive to the organization than one that does not show such features. Of course, building organizational trust is another, extremely important matter, and the choice of location in such an environment is only an introduction, as trust is easily destroyed and extremely difficult to build.

\section{The applied research method}

The study uses the results of studies carried out in the period from April-June 2014 on a sample of 1540 persons - students at public universities located in 16 capitals of the voivodships in Poland. In each of the regions, 88-100 people were questioned, who participated in three games connected with experimental economics and in a survey. Three games were used: "trust" (the trust game), a game called "public good" (the public good game) and the game "ultimatum" (the ultimatum game). In the paper the results of the games "trust" and "public good" were used, through which the inclination to trust, credibility and cooperation is measured. ${ }^{2}$

In the game 'public good' [Isaac, Walker 1988], the participants decide how much of their private means, which they receive in the experiment will be allocated to public purposes. The decision is made independently of other players. The total

2 Due to the limited volume of the paper, the description of the research method was reduced to the minimum. More on the research in: [Markowska-Przybyla, Ramsey 2015; Markowska-Przybyła, Ramsey 2014]. 
amount allocated to "public" purposes is multiplied by a value bigger than 1 and smaller than the number of players, and then it is distributed among all players, also among those who have not contributed towards the common pool. The maximization of payments for the players will take place if all players will contribute towards the common good all their means, however the Nash equilibrium will be achieved if the players will contribute nothing towards the common purpose. The Nash equilibrium occurs when the strategy of each player maximizes his/her personal payout while keeping the others, so when the strategy of each player is optimal, considering that the selection of other players is arranged [Rosenthal 1973]. However, the Nash equilibrium is rarely observed in experiments using the public good game [Gunnthorsdottir et al. 2007], even though the players do not have any individual motives to contribute anything to the pool. The amount of players' contributions show the attitudes of the so-called free-rider or may explain the pro-social attitude of players. In the game, each participant faces the necessity to choose between individual benefits and the benefits of the group, whereas the commitment towards the group may bring individual benefits (there is a risk however, that the cost of such commitment will exceed the benefits), but the lack of commitment may result in obtaining benefits (the attitude of free-rider). People who contribute the most to the common cash pool are called "cooperators", those who do not, defectors, free-riders. In the conducted research players had 20 zlotys at their disposal, the amount added to the common pool was multiplied by 1.6, and the group consisted of four people.

In the game "trust" suggested by Berg, Dickhaut and McCabe [Berg, Dickhaut, McCabe 1995], also called the investment game, two (usually anonymous) players take part. One player (A) has a certain amount of money (X). A part or all of this amount may be transferred (invested) - at its own discretion - to the other player (B); this is the amount $(Y)$. The $Y$ amount before it is transferred to the second player (B) is multiplied by factor $\lambda$ bigger that 1 , usually 2 or 3 . Both players know that. Then the second player (B) decides (independently from the first player), if a part the obtained amount $\lambda Y$ is transferred back. The trust game allows to examine trust (the part of the amount transferred by player A) and to examine credibility (solidarity) trustworthiness, which comprises a part of the $\lambda Y$ amount returned to the first player.

According to the assumption of rationality of behavior of units adopted in economics, player A should not pass anything to the other player (as they should assume that player B will behave rationally and will not return anything of the transferred amount). On the other hand, the second player should not return anything if they receive any amount. The Nash equilibrium occurs therefore then, when the first player passes nothing to the other player. However, experience shows that the players do not behave according to the assumption of rationality of behavior. This might be explained with the fact that player A expects a different behavior from player B than the one resulting from economic rationality, they are driven by trust, namely the assumption that player B will behave in a beneficial way for him/her (namely player A), risking a personal loss. Player A is also driven by an aversion to 
inequality, which causes some players, even wary ones, to transfer a small portion of their amount. In practice also the second player does not behave rationally from the economic point of view and passes a part of the amount back to player A. Such behavior is probably based on the standard of mutuality, player B transfers a part of the obtained amount as a response to the trust put in them. In the research, player A had 10 zlotys at his/her disposal, the amount transferred to player B was multiplied by 3. Half of the players played the role of A, the other - the role of B.

The participants of the study after completing games filled in a questionnaire regarding the attitudes and views aimed at indicating their social capital. The comparison of the results of both studies allowed to capture the intentionalbehavioral gap (not analyzed in this paper).

\section{The added value of social capital in Poland as a location factor - research results}

\subsection{Regional system}

The results of the research on the components of social capital in Poland, i.e. trust, credibility and cooperation, indicate that regional differences are not large, and are not statistically significant for trust and credibility, but there are significant differences for the observed cooperation ( $p=0.004$, KW test).

The highest level of cooperation (i.e. the share of the transferred amount for common purposes in the game 'public good') was characteristic for students of the Pomorskie, Małopolskie, Wielkopolskie and Zachodniopomorskie voivodeships (over 64\% of the transferred amount in the public good game), and the lowest for students of the Świętokrzyskie, Łódzkie, Mazowieckie and Podkarpackie voivodeships (below 56\%) (see Figure 1.a).

Considering all three elements that make up social capital: trust, credibility and cooperation, a synthetic measure illustrating the level of this capital has been created. Nevertheless, because it is difficult to clearly define what is most important in the context of social capital, especially in the long term: cooperation, credibility or trust, and what constellations can be considered more appropriate (e.g. cooperation with trust but with low credibility or cooperation with high credibility but low trust) that all three factors are equally important and on this basis the synthetic measure of social capital was built on the basis of the results of experimental research. The construction of the measure uses the formula of the unweighted arithmetic mean of normalized variable values: the average transfer in the game "public good", the average transfer of players A in the game "trust", the average transfer of players B corrected by the impact of the amount received in the game "trust". The results of the calculations are presented (see Figure 1.d). 
a)

The observed level of cooperation in the PG game - the average level of transfer in $\%$

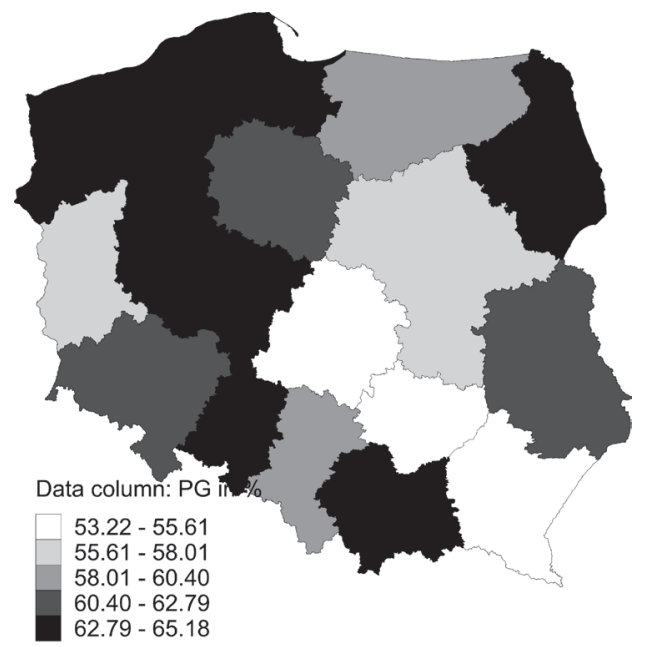

c)

The observed level of credibility in the game "trust" - the average level of transfer corrected impact of the amount received

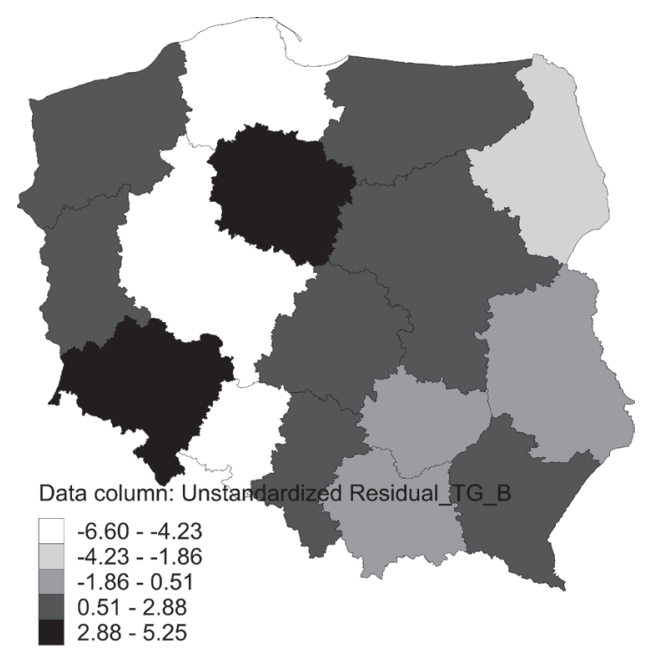

b)

The observed level of trust in the game "trust"the average level of transfer in \%

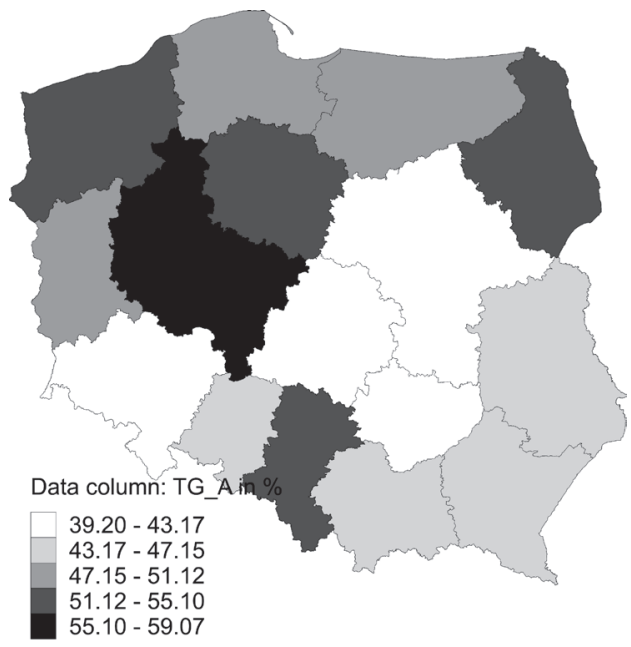

d)

Social capital - the synthetic measure of trust, credibility and cooperation

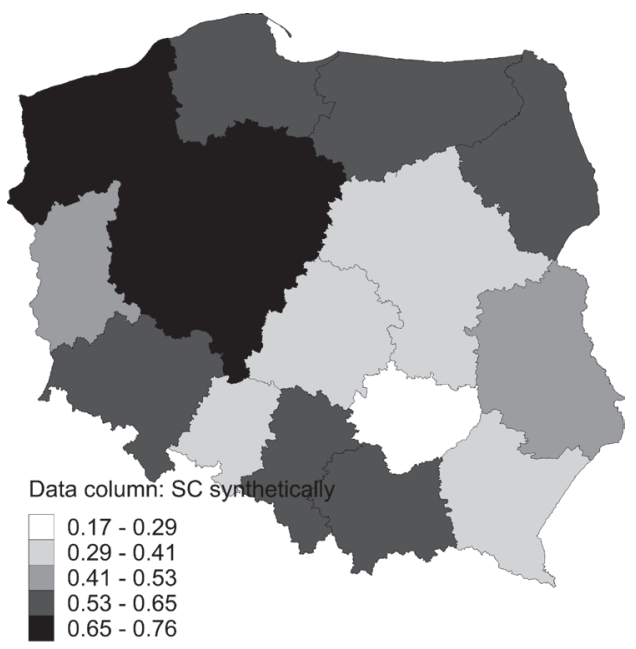

Fig. 1. Social capital in regions of Poland - components and the synthetic indicator

Source: own research.

The Świętokrzyskie voivodeship is a region with the lowest level of social capital defined in this way (0.17). This region is also characterized by the lowest levels of 
trust and cooperation, only credibility is at a higher level, which bodes well for the future. Higher credibility can become the basis for building a climate of trust. The highest level of social capital - in light of synthetic measure - is found in the Zachodniopomorskie and Kujawsko-Pomorskie voivodeships (0.76). In the former, all three components - cooperation, trust and credibility - show a high level, just as in the latter, and credibility is the highest in the country. The value structure of these three components is worrying for the Pomorskie and Wielkopolskie voivodeships: they are characterized by a fairly high level of trust and cooperation, but with low credibility. In the long run, this could mean a decline in overall confidence, as credibility is its primary pillar. Trust is, according to Sztopmka [2007, p. 148], an a priori assumption on the credibility of unknown people, strangers, of all people. Credibility is inseparable from trust, it is one of its pillars. Where people are credible, it is easier to trust. According to Russell Hardin [Hardin 2009, pp. 24-25] there are three different concepts of trust and all relate to the concept of credibility. Hardin even claims that they relate primarily to credibility and only indirectly to trust.

High values of synthetic measure are also the characteristics of: Śląskie, Podlasie, Małopolskie, Dolnośląskie, Warmińsko-Mazurskie, Lubuskie and Lubelskie (at least 0.5 synthetic measure). The areas of low social capital are - apart from Świętokrzyskie - the Mazowieckie, Łódzkie, Podkarpackie and Opolskie voivodeships.

\subsection{The arrangement in terms of village - city - metropolis}

The level of trust, cooperation and credibility is also different for different classes of localities, although statistically significant differences occur only for the level of trust ( $p=0.049, \mathrm{KW}$ test). With an average transfer for the entire sample at the level of $47.8 \%$ in the game "trust" in medium cities it was $43.96 \%$, and in large cities $51.52 \%$. (see Table 1). There are significant differences between large cities (high level of trust shown) and the smallest cities and medium-sized cities (low level of trust in the game).

The inhabitants of medium-sized cities (20 to 100 thousand inhabitants) show the lowest credibility, cooperation and trust, which should be assessed negatively from the point of view of their social capital. The inhabitants of the smallest towns (up to 5,000 inhabitants) are characterized by the highest reliability and the level of cooperation, with relatively low trust, while the inhabitants of large cities are characterized by a high degree of trust with lower credibility. Therefore, the assumptions that a high level of cooperation can exist without trust are confirmed. J. Pietrasik came to similar conclusions [Pietrasik 2006, see: Bednarek-Szczepańska 2013].

Similarly as in the case of regional differentiation, the synthetic measure was calculated, which indicates that the highest level of social capital defined in this way - considering with equal intensity of trust, cooperation and credibility - can be found in the smallest towns, then in small and large cities. Medium cities are characterized by the lowest level of this capital. 
Table 1. Social capital by size of municipality

\begin{tabular}{|l|c|c|c|c|}
\hline \multicolumn{1}{|c|}{ The size of municipality } & $\begin{array}{c}\text { Cooperation } \\
\text { (transfer in the } \\
\text { game "public } \\
\text { good" in \%) }\end{array}$ & $\begin{array}{c}\text { Trust (player } \\
\text { A's transfer in } \\
\text { the game "trust" } \\
\text { in \% }\end{array}$ & $\begin{array}{c}\text { Credibility } \\
\text { (player B's } \\
\text { transfer in the } \\
\text { game "trust" } \\
\text { in \%) }\end{array}$ & $\begin{array}{c}\text { Social capital } \\
\text { (synthetic } \\
\text { measure) }\end{array}$ \\
\hline $\begin{array}{l}\text { Municipality with up to } \\
5,000 \text { inhabitants }\end{array}$ & 61.54 & 45.52 & 35.06 & 0.74 \\
\hline $\begin{array}{l}\text { Small town (5,000-20,000 } \\
\text { inhabitants) }\end{array}$ & 59.45 & 50.63 & 34.27 & 0.58 \\
\hline $\begin{array}{l}\text { Medium-sized town (20,000- } \\
\text {-100,000 inhabitants) }\end{array}$ & 58.45 & 43.96 & 31.52 & 0.00 \\
\hline $\begin{array}{l}\text { Big city (over 100,000 } \\
\text { inhabitants) }\end{array}$ & 59.25 & 51.42 & 33.25 & 0.54 \\
\hline Total & 59.82 & 47.84 & 33.54 & - \\
\hline $\begin{array}{l}\text { Kruskal-Wallis test } \\
\text { (variable grouping, size of } \\
\text { municipality') }\end{array}$ & 0.255 & & & \\
\hline
\end{tabular}

Source: own research.

In the previous research the social capital of the smallest towns was often negatively assessed. ${ }^{3}$ According to experimental research, these cities seem to have strong social capital (especially in the Kujawsko-Pomorskie and Śląskie voivodeships); the social capital of these cities also shows diversity between the following regions: Silesia, Wielkopolska and Małopolska differs from the Świętokrzyskie, Podkarpackie and Mazowieckie voivodeships. The low social capital of middle-sized cities is worth consideration. Finding the reasons for such a situation requires further research, however, a hypothesis might be formulated concerning the loss of importance of the socio-economic position of middle-sized cities as a result of the administrative reform in 1999. [Markowska-Przybyła 2014].

It is interesting to isolate a separate class of cities from large cities, the so-called metropolis. ${ }^{4}$ The following were considered as such: Warsaw, Kraków, Łódź, Wrocław, Poznań, Trójmiasto (i.e. Gdańsk, Gdynia, Sopot), the statistical Katowice sub-region and Szczecin; 239 respondents lived in those. There are relatively large differences between them, they differ in terms of trust $(p=0.060)$ and reliability $(p=0.065)$. Players A in the game "trust", who are residents of Gdańsk and Poznań (the former Prussian-annexed territory), made up 56\% more than the inhabitants of Łódź and Warsaw (the former Russian domains) and 40.5\% more than the residents of Kraków (formerly incorporated into the Austro-Hungarian Empire). However,

3 In previous research on Polish social capital, there are differences between the social capital of villages and cities, especially large cities. This diversity was observed by K. Janc [2006], J. Herbst [2005], T. Żukowski [2007], J. Działek [2011], and also the authors of the Social Diagnosis [Rada Monitoringu Społecznego 2015].

4 Cf.: [Markowska-Przybyła, Potocki, Ramsey 2017]. 
those (the residents of Kraków) were the most reliable - players B returned on average $49 \%$ of their amount (with the average for Poland 33.5\%). Reliable - against the background of other metropolises - also turned out to be the residents of the formerly Russian territory (33.6\%); they are more credible than the inhabitants of the former Prussia and the so-called Western and Northern borderlands. The inhabitants of the Katowice sub-region proved to be the least reliable (21.5\%).

Table 2. Trust, cooperation and credibility in historical regions and in rural, urban and metropolitan areas according to experimental data

\begin{tabular}{|l|c|c|c|}
\hline \multicolumn{1}{|c|}{ Specification } & $\begin{array}{c}\text { Cooperation } \\
\text { (average transfer } \\
\text { in percentage } \\
\text { in the game } \\
\text { of public good) }\end{array}$ & $\begin{array}{c}\text { Trust } \\
\text { (average transfer } \\
\text { in percentage } \\
\text { of A players } \\
\text { in the trust game) }\end{array}$ & $\begin{array}{c}\text { Credibility } \\
\text { (average transfer } \\
\text { in percentage } \\
\text { of B players } \\
\text { in the trust game) }\end{array}$ \\
\hline Rural areas & 61.2 & 46.0 & 33.5 \\
\hline Urban areas & 59.4 & 47.8 & 34.3 \\
\hline Metropolis & 58.6 & 50.8 & 30.5 \\
\hline $\begin{array}{l}\text { Kruskal-Wallis test } \\
\text { (grouping variable, ,area } \\
\text { type") }\end{array}$ & 0.303 & & \\
\hline
\end{tabular}

Source: own research.

In the metropolitan population group, lower credibility and weaker commitment to cooperation for the common good are observed than in other cities and among rural residents, while trust is the highest (see Table 2). However, these differences are not statistically significant for all respondents.

\section{Relationships with economic effects}

The results of the study on the relationship between social capital and economic effects are varied, but there are a number of studies indicating the positive relationship. The author's original research does not indicate any direct dependencies (no statistically significant relationships between social capital and GDP per capita and economic growth), but social capital identified by means of the experiment method (primarily the level of cooperation) seems to be an indirect factor of the level of development related to the level of labor productivity and total productivity of production factors. ${ }^{5}$

5 Total productivity of production factors is equated with long-term macroeconomic production efficiency. This is a part of the increase in production that is not explained by the increase in expenditure of the basic growth factors of capital and labour. The factors determining its growth are innovation, technical progress, infrastructure development, institutions and social capital [Dettori, Marrocu, Paci 2012; Isaksson 2007]. Its idea and detailed method of its calculation were presented in the publication [Tokarski 2010]. 
Excluding the Mazowieckie voivodeship from the analysis, which significantly differs from the rest of the regions in terms of economic results, there is a specific statistically significant correlation between the synthetic indicator of social capital and labour productivity a $(r=0.61, p<0.02$, Spearman's correlation coefficient), and the total productivity of factors of production $(\mathrm{r}=0.58, \mathrm{p}<0.03$, the Spearman correlation coefficient), as well as between the level of observed cooperation and labour productivity $(r=0.59, \mathrm{p}<0.02)$ and TFP $(r=0.56, p<0.05)$ (see Table 3 ).

Total productivity of production factors is equated with long-term macroeconomic production efficiency. This is the part of the increase in production that is not explained by the increase in expenditure of the basic growth factors, capital and labour. The factors determining its growth are innovation, technical progress, infrastructure development, institutions and social capital [Dettori, Marrocu, Paci 2012; Isaksson 2007].

Table 3. Correlations between social capital and the level of cooperation, and labour productivity and TFP in 15 regions of Poland

\begin{tabular}{|l|c|c|}
\hline $\begin{array}{c}\text { Spearman's rank correlation coefficient } \\
(N=15)\end{array}$ & TFP 2014 & Work efficiency \\
\hline Synthetic indicator of social capital & 0.58 & 0.61 \\
\hline Level of cooperation & 0.56 & 0.59 \\
\hline
\end{tabular}

Source: own computation.

\section{Conclusion}

For some entrepreneurs or managers, information on social capital resources may prove to be crucial. By locating the company in a favourable environment, one can get an additional added value, allowing to gain a competitive advantage. The role of soft factors increases, and is particularly important when other factors remain at a similar level. Knowledge about the diversity of social capital can be quite important, especially if it is based on reliable observations, rather than subjective declarations of the feelings of the respondents.

Research based on economic experiment indicates that in the interregional system large differences are visible, however some patterns are similar to those of historical systems. First of all, there is a low level of social capital of the former Russian-annexed territories in contrast to the higher resources of this capital of the former Prussian domains, Western and Northern borderland territories. ${ }^{6}$

6 The highest confidence was observed in the former Prussian domain, i.e. the average transfers of A players in the trust game (hereinafter: TG-A) were the highest there and averaged $56.8 \%$, which meant that they were $26.2 \%$ higher than in the former Russian domain, where the transmission was the lowest (45\%). Only this variable differentiates the regions statistically significantly (the Kruskal-Wallis test, $p=0.023$ ). The ratio of the highest average transmission to the lowest is 1.26 , while in 
In light of the experimental research, the regions with the largest social capital resources are:

- Kujawsko-Pomorskie voivodeship - high level of trust, credibility (the highest level in the country) and cooperation. High ratio of trustful to distrustful people.

- Zachodniopomorskie voivodeship-high level of trust, credibility and cooperation - small percentage of free-riders.

The region with the lowest resources of the capital in question is the Świętokrzyskie voivodeship. This region is also characterized by the lowest levels of trust and cooperation, only credibility is at a higher level, which bodes well for the future.

The Pomorskie and Wielkopolskie voivodeships are difficult to interpret clearly. One can there observe a high level of trust and cooperation but the level of credibility, which is the pillar of trust, is low.

The residents of large cities show a high degree of trust. However, they also show relatively low credibility, while the inhabitants of the smallest towns (up to 5,000 inhabitants) are characterized by the highest reliability and the level of cooperation, with relatively low trust, which perhaps is connected with wealth. Wealthy people have relatively less to lose, hence more often show attitudes of trust. On this assumption, the social capital of the smallest towns should be assessed positively. The social capital of medium-sized cities is least favourable: they show, on average, the lowest credibility, cooperation and trust.

The study equally valued trust, credibility and cooperation in the assessment of social capital. However, there are premise that credibility can be more important than trust - commonly used to assess capital resources. The very taking credibility into account in the research acknowledges these premises, which only some research do.

Although generalized trust is referred to in many definitions of social capital, and is a commonly accepted measure of this capital, not everyone considers trust an indispensable element of cooperation, facilitating it and contributing to raising prosperity. This is not even about trusting one's own people, which is a manifestation of binding social capital and in some cases can even have negative consequences for the general public. Not every trust is positive, and distrust can act as a positive feature, for example the rational distrust with regard to people unworthy of trust. Trust and distrust are reinforced epistemologically, then they are functional [Sztompka 2002, p. 322]. Kochanowicz [2004, p. 68] notes that trust is only one of the dimensions of cooperation. Other, closely related but separate dimensions are social skills to work and function within a given social organization. According to

the game for the public good (hereinafter: $\mathrm{PG}$ ) only 1.05, and in the game of trust (players B, showing credibility - hereinafter: TG-B): 1.12. The significant differences (the Mann-Whitney test) in the TG-A exist between the former Prussian domains and those formerly in Russia and Austro-Hungarian Empire, and the Western and Northern Borderland Territories. The former Prussian domain did not differ statistically in this respect from Upper Silesia. More on this subject in [Markowska-Przybyła et al. 2017]. 
Hardin [2009, p. 88], cooperation is even possible in the absence of trust due to the diversity of social tools such as standards or institutions. It is also enabled by legal norms, informal methods of social control, moral principles, religion or social norms of cooperation and responsibility [Cook, Hardin, Levi 2005, pp. 83-97]. Therefore, perhaps credibility and the desire to maintain it is just as important for cooperation, and even more important than trust, as it is its pillar. This problem was also noted by Ambroziak, Starosta and Sztaudynger [2016], who in their analyses do not narrow social capital to trust, but broaden it with two other components - honesty (reliability) and a general tendency to help others. They treat trust as only one (nevertheless the most important) component of cooperation capital.

\section{Bibliography}

Ambroziak E., Starosta P., Sztaudynger J., 2016, Zaufanie, skłonność do pomocy i uczciwość a wzrost gospodarczy w Europie, Ekonomista, 5, pp. 647-671.

Arrow K.J., 1972, Gifts and exchanges, Philosophy \& Public Affairs, 1(4), pp. 343-362.

Barney J., 1991, Firm resources and sustained competitive advantage, Journal of Management, 17(1), pp. 99-120.

Bartkowski J., 2007, Kapitał społeczny i jego oddziaływanie na rozwój w ujęciu socjologicznym, [in:] M. Herbst (ed.), Kapitał ludzki i kapitał społeczny a rozwój regionalny, Scholar, Warszawa.

Bednarek-Szczepańska M., 2013, Wiejski kapitał społeczny we współczesnej Polsce: Przegląd badań $i$ uwagi metodyczne, Acta Universitatis Lodziensis. Folia Geographica Socio-Oeconomica, (no. 13: Koncepcje i problemy badawcze w geografii wsi), pp. 19-40.

Berg J., Dickhaut J., McCabe K., 1995, Trust, reciprocity, and social history, Games and Economic Behavior, 10(1), 122-142.

Coleman J.S., 1988, Social capital in the creation of human capital, American Journal of Sociology, no. 94 , pp. 95-120.

Cook K.S., Hardin R., Levi M., 2005, Cooperation Without Trust?, Russell Sage Foundation, New York.

Czapiński J., 2008, Kapitat ludzki i kapitał spoteczny a dobrobyt materialny. Polski paradoks. Zarządzanie Publiczne, 2(4).

Czapiński J., Panek T., 2009, Diagnoza społeczna 2009. Warunki i jakość życia Polaków, Rada Monitoringu Społecznego, Warszawa.

Czapiński J., Panek T., 2015, Diagnoza Społeczna 2015. Warunki i jakość życia Polaków, Rada Monitoringu Społecznego, Warszawa.

Czyżewski B., 2009, Współczesne teorie renty gruntowej, ich geneza i znaczenie dla Wspólnej Polityki Rolnej w UE, Zeszyty Naukowe Szkoły Głównej Gospodarstwa Wiejskiego w Warszawie. Polityki Europejskie, Finanse i Marketing, no. 2, t. 1.

Dettori B., Marrocu E., Paci R., 2012, Total factor productivity, intangible assets and spatial dependence in the european regions, Regional Studies, 46(10), pp. 1401-1416.

Działek J., 2011, Kapitat społeczny jako czynnik rozwoju gospodarczego w skali regionalnej i lokalnej $w$ Polsce, Wydawnictwo Uniwersytetu Jagiellońskiego, Kraków.

Fukuyama F., 1997, Social capital and the modern capitalist economy: creating a high trust workplace, Stern Business Magazine, no. 4. 
Gunnthorsdottir A., Houser D., McCabe K, 2007, Disposition, history and contributions in public goods experiments, Journal of Economic Behavior \& Organization, 62(2), pp. 304-315.

Hardin R., 2009, Zaufanie, Wydawnictwo Sic!, Warszawa.

Herbst J., 2005, Oblicza społeczeństwa obywatelskiego, Fundacja Rozwoju Obywatelskiego, Warszawa. Isaac R.M., Walker J.M., 1988, Group size effects in public goods provision: the voluntary contributions mechanism, The Quarterly Journal of Economics, 103(1), pp. 179-199.

Isaksson A., 2007, Determinants of Total Factor Productivity: A Literature Review, United Nations Industrial Development Organization (UNIDO).

Janc K., 2006, Human and Social Capital in Poland. Spatial Diversity and Relations, [in:] T. Komornicki, K. Czapiewski (eds.), Core and peripheral regions in Central and Eastern Europe, PTG, IGiPZ PAN, Warsaw, pp. 39-55.

Knowles S., 2006, Is Social Capital Part of the Institutions Continuum and is it a Deep Determinant of Development?, Research Paper No 25, UNU-WIDER.

Kochanowicz J., 2004, Trust, Confidence, and Social Capital in Poland: A Historical Perspective, [in:] I. Markova (ed.), Trust and Democratic Transition in Post-Communist Europe, OUP/British Academy, New York, pp. 63-83.

Kopczewska K., 2008, Renta geograficzna a rozwój społeczno-gospodarczy, Wydawnictwa Fachowe CeDeWu, Warszawa.

Markowska-Przybyła U., 2010, Kapitat społeczny jako czynnik rozwoju regionalnego, [in:] W. Kosiedowski (ed.), Kapitat ludzki w procesie przemian Europy Środkowej $i$ Wschodniej. Aspekty makroekonomiczne i regionalne, Dom Organizatora TNOiK, Toruń, pp. 75-86.

Markowska-Przybyła U., 2014, Kapitał społeczny matych miast Polski, Problemy Rozwoju Miast, no. 3, pp. 29-38.

Markowska-Przybyła U., Ramsey D., 2014, A game theoretical study of generalised trust and reciprocation in Poland: I. Theory and experimental design, Operations Research and Decisions, no. 3, pp. 59-77.

Markowska-Przybyła U., Ramsey D., 2015, A game theoretical study of generalised trust and reciprocation in Poland: II. A description of the study group, Operations Research and Decisions, no. 2, pp. 51-73.

Markowska-Przybyła U., Potocki J., Ramsey D., 2017, Przestrzenny wymiar zróżnicowania kapitału społecznego w Polsce w świetle badań eksperymentalnych, Studia Regionalne i Lokalne, 4.

Pietrasik J., 2006, Tradycje współdziałania na wsi a kapitat społeczny, Uniwersytet Warszawski, Warszawa.

Pogonowska B., 2004, Kapitat społeczny - próba rekonstrukcji kategorii pojęciowej, [in:] H. Januszek (ed.), Kapitat społeczny - aspekty teoretyczne i praktyczne, Wydawnictwo Akademii Ekonomicznej w Poznaniu, Poznań.

Putnam R.D., 1995, Demokracja $w$ działaniu: Tradycje obywatelskie we współczesnych Włoszech, Wydawnictwo Znak, Kraków.

Rosenthal R.W., 1973, A class of games possessing pure-strategy Nash equilibria, International Journal of Game Theory, vol. 2, no. 1, pp. 65-67.

Sztompka P., 2002, Socjologia. Analiza spoteczeństwa, Wydawnictwo Znak, Kraków.

Sztompka P, 2007, Zaufanie: Fundament spoleczeństwa, Wydawnictwo Znak, Kraków.

Tokarski T., 2010, Przestrzenne zróżnicowanie łącznej produkcyjności czynników produkcji w Polsce, Gospodarka Narodowa, no. 3, pp. 23-39.

Woźniak M.G., 2008, Wzrost gospodarczy. Podstawy teoretyczne, Wydawnictwo Uniwersytetu Ekonomicznego w Krakowie, Kraków.

Żukowski T., 2007, Kapitał społeczny w Polsce lokalnej. Przestrzenne zróżnicowanie na początku XXI w., [in:] E. Leś, M. Ołdak (eds.), Przedsiębiorstwo społeczne w rozwoju lokalnym, Collegium Civitas Press, Warszawa. 